ENTREPRENEURSHIP AND SUSTAINABILITY ISSUES

ISSN 2345-0282 (online) http://jssidoi.org/jesi/

2020 Volume 7 Number 3 (March)

http://doi.org/10.9770/jesi.2020.7.3(40)
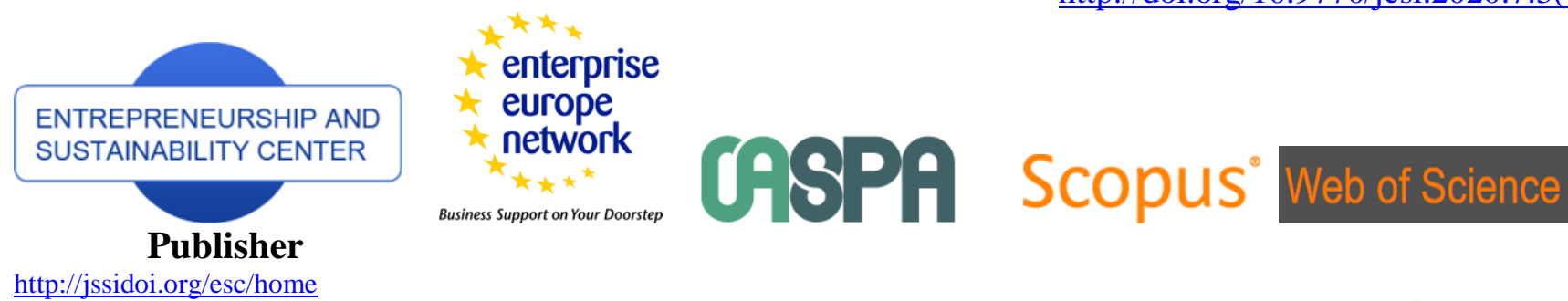

http://jssidoi.org/esc/home

\title{
THE CONTRIBUTION OF MACROECONOMIC FACTORS IN DETERMINING THE ECONOMIC GROWTH, EXPORT AND THE AGRICULTURAL OUTPUT IN AGRI-BASED ASEAN ECONOMIES
}

\author{
Paitoon Chetthamrongchai ${ }^{1}$, Sudawan Somjai ${ }^{2 *}$, Thitinan Chankoson ${ }^{3}$ \\ ${ }^{1}$ Faculty of Business Administration, Kasetsart University, Bangkok, Thailand \\ 2 Graduate School, Suan Sunandha Rajabhat University, Bangkok, Thailand \\ 3 Faculty of Business Administration for Society, Srinakharinwirot University, Bangkok, Thailand \\ E-mails: ${ }^{1}$ fbusptc@ku.ac.th ; ${ }^{2 *}$ sudawan.so@ssru.ac.th (Corresponding author); ${ }^{3}$ thitinanc@swu.ac.th
}

Received 12 August 2019; accepted 12 January 2020; published 30 March 2020

\begin{abstract}
The prime objective of the study can be looked at from the theoretical and practical perspectives thereby predicated on the researcher's strong will to contribute to the body of knowledge by analyzing the economic impact of government spending on agriculture, unemployment rate, and crude oil price in the context of agriculture sector of non-oil for economic growth. Moreover, with the aims to bridge the literature gap in the knowledge of macroeconomic factors on the agriculture in Thailand; since the non-oil export has the potential of growth in terms of sales, profitability, rate of earnings and productivity if the factors militating against the non-oil exports are addressed. The ARDL method is employed to answer the research questions. The findings of the study ha highlight the fact that the this is not only to increase the agricultural sector's contribution to GDP but can also help to cushion the effect of price shocks in the international oil (crude oil) market and promote non-oil export. In addition, to improve the outlook of other non-oil sectors such as the manufacturing sector where agricultural outputs are being required. Thus, important macroeconomic factors like the interest rate, agricultural land, unemployment rate, agricultural export, crude oil price, inflation rate, government spending, openness and exchange rate will be considered in the study.
\end{abstract}

Keywords: economic growth; agriculture output; macroeconomic factors; Thailand

Reference to this paper should be made as follows: Chetthamrongchai, P., Somjai, S., Chankoson, T. 2020. The contribution of macroeconomic factors in determining the economic growth, export and the agricultural output in agri-based ASEAN economies. Entrepreneurship and Sustainability Issues, 7(3), 2043-2059. https://doi.org/10.9770/jesi.2020.7.3(40)

JEL Classifications: Q13, Q17

\section{Background}

Economic growth is a worldwide concern of countries that can be mirrored in country's Gross Domestic Product (GDP). Economic growth is also linked with national economic size of a country. Micro and macro-economic factors can determine economic growth of a country (Meade, 2013; Vigliarolo, 2020). However, GDP is largely influenced by macroeconomic factors which can determine the trend that a country's economy is positioned. Hence it is important to make further investigation of macroeconomic factors on economic growth; for improving and achieving rise in standard of living worldwide. Many macroeconomic factors can be identified as the primary source of economic growth where export is one of the vital factors (Berg \& Lewer, 2015). There have been a 
ENTREPRENEURSHIP AND SUSTAINABILITY ISSUES

ISSN 2345-0282 (online) http://jssidoi.org/jesi/

2020 Volume 7 Number 3 (March)

http://doi.org/10.9770/jesi.2020.7.3(40)

considerable number of studies in economic development and growth literature concerning the exports significance as an engine for economic growth. It has been widely acknowledged in theory as well as in practice that exportation leads to several economic benefits for a country. Such as income growth, foreign exchange earnings used to finance imported goods and advancement in technology (Verter \& Bečvářová, 2016; Eddelani et al., 2019; Caurkubule et al., 2020). Likewise, export commodity by a country represents one of the important sources of foreign income that ease pressure on balance of payments (BOP) and generate employment. Hence, these economic benefits made exportation significant for both developing and developed countries. Therefore improvement is needed in their outputs for export promotion (Doki, Ochinyabo, \& Sule, 2018; Sindhu, Babar, \& Abbas, 2018; Zeibote et al., 2019).

Export promotion involves encouraging domestic production for exportation usually by providing incentives for domestic producers. Increasing exports are important not only for developing but also developed economies, since the growth of export has forward and backward links to all sectors in the economy. Many countries have engaged in export promotion strategy far back in 1970 as part of the most proficient gears for growth and development because export has been regarded as a catalyst for the overall economic development (Amado \& Mollo, 2015; Danylova \& Kats, 2019; Keho, 2017). The ASEAN countries accounts for the 11 percent of world's agriculture output (see figure 1).

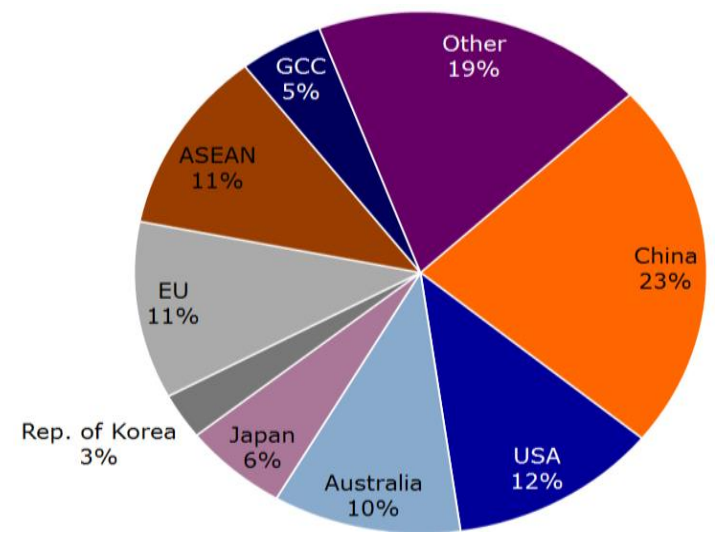

Figure 1. The agriculture output (country and region)

Evidences by most economists based on the 1970s and 1980s experiences assumed that good macroeconomic policies are essential and adequate for the achievement of sustainable growth in the long run. Hence, macroeconomic factors which consists of fiscal, monetary and trade policies influence economic growth. Since all the policies (fiscal, trade and monetary) are interdependent, macroeconomic policies can therefore be defined as policy mix. Thailand as an example of a developing nations has embraced various policy mix in the means of improving the overall feasibility of the country's economy performance. Although several policies are being designed by the government to improve Thailand 's economy as a whole, some policies often have causal and detrimental effects on output growth. For instance, the falling of global commodity price and increasing of world crude prices of recent have become more challenging for government in stimulating the economy without endangering macroeconomic stability (Gilpin, 2018). Hence, associate the improvement of macroeconomic factors to be anchored to the nations' growth. The five countries used as a sample of the study accounts for 95 percent of ASEAN's GDP (see figure 2). 
ENTREPRENEURSHIP AND SUSTAINABILITY ISSUES

ISSN 2345-0282 (online) http://jssidoi.org/jesi/

2020 Volume 7 Number 3 (March)

http://doi.org/10.9770/jesi.2020.7.3(40)

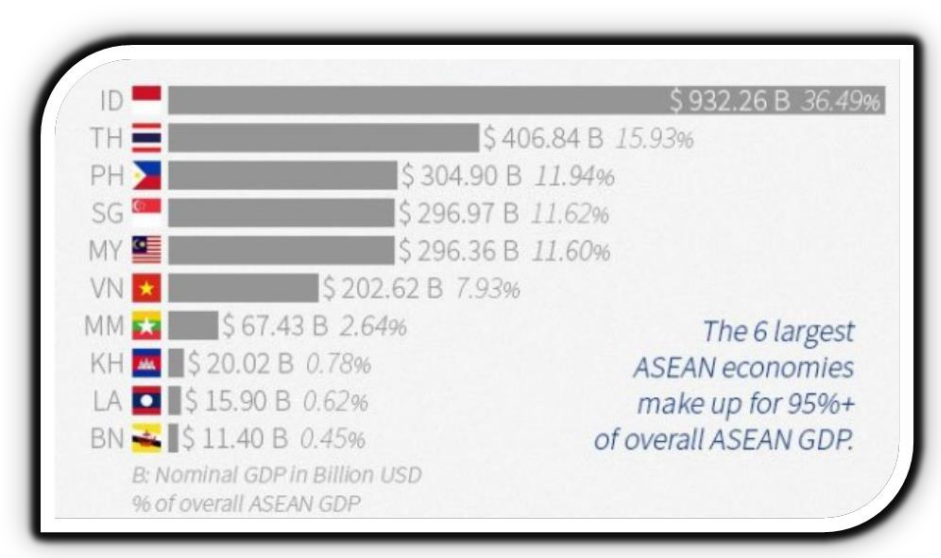

Figure 2. The share of each ASEAN country in aggregate ASEAN GDP

Source: World Bank

Furthermore, the international financial crisis which began in 1997 continues to affect the external trade of agricultural sector. In the case of Thailand, changes in macroeconomic factors such as exchange rate improved the agricultural sector performance. Likewise, Adekunle and Ndukwe (2018) observed that changes in exchange rate, interest rate and other macroeconomic factors have considerable impact on Thailand 's agricultural sector. However, the downward trend of agricultural sector revealed can be ascribed to the influences of some of these macroeconomic factors. Hence, making investigation on macroeconomic factors crucial for future performance of the economic growth of nations and also agricultural sector. This is not only to increase the agricultural sector's contribution to GDP but can also help to cushion the effect of price shocks in the international oil (crude oil) market and promote non-oil export. In addition, to improve the outlook of other non-oil sectors such as the manufacturing sector where agricultural outputs are being required. Thus, important macroeconomic factors like the interest rate, agricultural land, unemployment rate, agricultural export, crude oil price, inflation rate, government spending, openness and exchange rate will be considered in the study. Despite exportation in developing countries have been proposed to enhance revenue and usher in economic growth and development (Berg \& Lewer, 2015; Esu \& Udonwa, 2015) diversity of Thailand 's exports base can still be identified to give a better way of achieving economic growth (George-Anokwuru, 2018). More so, potential access from export encouragement through macroeconomic factors could be considered, as successful development relies upon policies.

Furthermore, for critical addressing of problem militating subsectors of non-oil performance in view of the fact that "oil is an exhaustible asset", sectoral analysis is necessary which few studies have examined. This thereby raised the needs for investigating the sectoral components of non-oil such as agriculture for proper managing and improvement through some macroeconomic policies by the government that will aid its output and exportation. Similarly, agriculture has been concluded to be an engine of economic growth and development through its important roles like serving as other raw products for other non-oil sectors, basis of food to man, poverty reduction in most nations (Luca, Cionga, \& Giurca, 2013; Oluwatoyese \& Razak, 2016) and constituting the largest share of the nonoil with limited work facilitate the direction for this study. Hence impact of inflation rate, crude oil price, unemployment rate, government spending on agriculture, SAP, exchange rate and agricultural land on the economy are being examined for better output growth and positioning of diversity in export base.

The quest for this study can be looked at from the theoretical and practical perspectives thereby predicated on the researcher's strong will to contribute to the body of knowledge by analyzing the economic impact of government spending on agriculture, unemployment rate, and crude oil price in the context of agriculture sector of non-oil for 


\section{ENTREPRENEURSHIP AND SUSTAINABILITY ISSUES}

ISSN 2345-0282 (online) http://jssidoi.org/jesi/

2020 Volume 7 Number 3 (March)

http://doi.org/10.9770/jesi.2020.7.3(40)

economic growth. Moreover, with the aims to bridge the literature gap in the knowledge of macroeconomic factors on the agriculture in Thailand ; since the non-oil export has the potential of growth in terms of sales, profitability, rate of earnings and productivity if the factors militating against the non-oil exports are addressed. Likewise, Sindhu et al. (2018) concluded that stabilization economic policies that will boost export promotion and productivity should be sustained and implemented; in wise of government policies stimulating agricultural productivity being examined. This will be of important for policy making in developing countries of the world especially Thailand for the design of macroeconomic policies in order to promote export through the aid of the agriculture sector; whereas leading towards improvement in economic growth. Likewise, since the role of agriculture in transforming the economy cannot be overstressed by serving as the source of food for human and animal and provides raw materials for industrial sector. More so playing a significant role in the reduction of poverty of nations (Rashwan, Ragheb, \& Bary, 2018), therefore calls for enhancing agricultural sector performance. Also, the research study must be able to explain succinctly components of non-oil in Thailand $n$ growth; so as to be able to examine the structure and policies needed to be put in place as regarding to the improving of the country's agricultural sector.

\section{Literature Review}

Literature on economic growth concept has been explored which make this study to agree with the definitions of Meade (2013), Lewis (2013). The study acclaims that economic growth is the increment in consumption of services and goods and its production, and it's mirrored in country's gross domestic product (GDP). The effect of micro and macro-economic factors such as GDP per capita to be positive, zero and negative with a nation's economic growth. He asserted that there is positive economic growth effect if the macro-economic factors are found to be higher than the country population growth. Zero economic growth occurs when these factors are equal to the population growth whereas negative economic growth is obtained when population growth are higher than these factors. Assertion supported Barro (2016) conclusion that economic growth has a significant relationship with a country's resources, infrastructure development, institutional development, government intervention and culture. Lincényi and Čársky (2020) emphasized importance of trust in public policy. However, Bagli and Adhikary (2014) argued that one of the factors that also face economic growth is population growth. Therefore, past works were reviewed with consideration on few macroeconomic factors on economic growth that are necessary in this study.

\section{Exchange Rate}

Fariditavana (2016) measured the impacts of the real exchange rate (RER) on the balance of payment (BOP) using structural cointegrating vector autoregressive distributed lag (VARDL) models for local and international output. Eight organization for economic cooperation and development (OECD) nations with small structures were estimated to examine long-run relationship. The impulse response functions (IRF) were summed to study the response to shocks, showing an indication of J-effects curve; that is worse off of the country's trade deficit at the start of its currency's depreciation. The estimation used a single-equation autoregressive distributed lag (ARDL). The outcomes suggested that the maximum likelihood condition is satisfied in the long run, despite the considerable heterogeneity discovered.

Scott (2015) deliberated on exchange rate strategy, in relation to Chinese financial and capital control reform; using general regional equilibrium of input-output for empirical results. The results signify that there are other options to renminbi/dollar appreciation strategy in managing US China tenacious trade deficiency ought to be given. In this way, offering another and exact based arrangement suggestion in managing the US exchange shortage with China was made. Likewise, Habib, Mileva, and Stracca (2017) examined how a high RER stimulates economic development for developing countries. The finding used different estimation techniques and RER measurements, because of its robustness in nature. The results suggested that tradable suffer excessively from the government failures that keep poor countries from uniting toward countries with higher incomes; while 


\section{ENTREPRENEURSHIP AND SUSTAINABILITY ISSUES}

ISSN 2345-0282 (online) http://jssidoi.org/jesi/

2020 Volume 7 Number 3 (March)

http://doi.org/10.9770/jesi.2020.7.3(40)

official model clarified relationship between RER and economic appreciation. Since linkage between exchange rate and economic development exist in developing nations, therefore existence is obvious in most ASEAN nations.

Mohsen (2015) studied effect of exchange rate, inflation rate and interest rate on the non-oil sector as whole. Their study concluded that non-oil export was said to have progressive outcome on economic development; thereby recommended that increase in production of agricultural and manufacturing sectors have to be ensured for product availability in both domestic and export purposes. Adegboyo (2019) examined the relationship between the country's RER and domestic output growth. The study adopted the error correction model technique and found that there is no co-integration between RER and other explanatory variables on the long run. The study revealed that RER is to operate through aggregate supply chain, which can enhance output expansion and economic expansion at large in Thailand. Therefore, the study suggested that, there is need to use real exchange rate as one of the macroeconomic policies to assist an economy.

\section{Interest Rates}

Another macroeconomic factor that influences economic growth greatly is interest rates. Bodenstein, Erceg, and Guerrieri (2017), stated that interest rate is the annual price charged from a borrower on a loan and it's express as percentage of the total loan. Bruno and Shin (2015) assert that it's the profit over a period of time which is gotten from financial instrument. It can also be view as the difference in money back and money initial given over a period of time. The interest rates phenomenon explains how commercial banks make their revenue and which is found have influence on a country's economy. Author investigated the determinants of huge capital flight along with its constraints on economic growth. The study analysed the capital flight of Thailand in a new context by different innovative model and econometric techniques. This study was carried out with use of the ordinary least squares (OLS) and the error correction model (ECM). The study found that interest rate causes capital flight in both Thailand's short and long run; while exchange rate depreciation significantly increases capital flight. Output growth in the short run was significant and negative, indicating that non-active home resources can trigger capital flight.

\section{Inflation Rate}

Inflation is another major macroeconomic factor that influences economic growth. It can be explained as the annual continuous inflation in product's price and service in the country's unit of currency (Maravalle \& Rawdanowicz, 2018). It is an annual rate that is reflected in a country's price of good and services which directly influence the country index of money prices. Scholar pointed out that inflation rates indicates that there is continuous fall in the total purchase power of a country's monetary system and its effect will be directly felt on the country's economic growth. Also, non-considered fact was assumed, whereas flexible exchange rate era with inflation aiming, showed that inflation would have been reduced, but interest rate instability would have been amplified.

Similarly, Bon (2018), examined "long-run relationships and threshold effects between Mexico's inflation and economic growth". Employing cointegration technique, they found that there exist significant and undesirable long-run association between inflation and economic progression. Their result also observed high level of inflation produce a destructive effect on economic development which is consistence with other studies. In Africa, Hassan and Nassar (2017) observed whether inflation causes South Africa's growth. Employment rate was incorporated into the model as variable affecting both inflation and economic growth, so as to address the problem of omitted variable associated with some previous studies. A bidirectional causal relationship was found between inflation and economic development in South Africa by using ARDL approach. Likewise, in Thailand, Obi, Yuni, and Ihugba (2016) carried out a study on economic growth and inflation. Consumer price index (CPI) and GDP were used as a substitute for inflation and economic development respectively using cointegration and 


\section{ENTREPRENEURSHIP AND SUSTAINABILITY ISSUES}

ISSN 2345-0282 (online) http://jssidoi.org/jesi/

2020 Volume 7 Number 3 (March)

http://doi.org/10.9770/jesi.2020.7.3(40)

causality test. No co-integrating existence was discovered variables for the period. VAR-Granger causality also resulted at unidirectional causality running from inflation to growth. It was stated that inflation has no good impact on growth and the fact was maintained in the case of country with high inflation.

\section{Unemployment Rate}

The ratio of the labor force within a country is referred to as employment and is one of the leading macroeconomic factors that influence a country's economic growth. Similarly, Cylus, Glymour, and Avendano (2014) explained unemployment rate as the measurement of employable force within a country's workforce which is expected to be 16 years and above and the unengaged force (either those that have lost their job or/and unable to secure a job within last one month). It is a fact that when there is positive economic growth in a country then it be influential on the employment rate of the citizen. There is an affirmative association between India's growth and employment rate which supported Keynesian theories. He concluded that increment in fiscal development will lead to an increase in the employment ratio of a country.

Chand, Tiwari, and Phuyal (2017) examined the effect of unemployment rate on GDP alongside with macroeconomics variables such as government deficit spending, interest and inflation rate. It was discovered that government deficit spending and unemployment rate has a negative effect; while inflation and interest rate had no significant effect on GDP. More recently, the interdependence in national labour markets in Central America, by constructing two sets of panel data. Vector Auto Regression (VAR) models that included the economic growth, investment, and unemployment rates; and export ratios in place of the investment rates are used for estimation. Likewise, Kashi and Tash (2014) analysed impact of inflation, unemployment rate and government expenditure on poverty level in Iran. The study revealed that unemployment and inflation have positive impact on poverty; whereas government expenditure has no tangible effects on poverty.

The forecasts accuracy of some macroeconomic variables in Romania. ARIMA models were used for prediction of the inflation and the unemployment rate, while it was concluded that the unemployment forecasts were better than the naïve predictions and the static prognosis were superior to the dynamic. Kaas and Kircher (2015) examined two-country and sector model whereas one sector produces homogeneous products and the other differentiated products for trade. The relationship of labour market rigidities and trade weaknesses in repositioning welfare, trade flows, productivity, and unemployment are also studied. The opening to trade increases rate of unemployment for a country if relative labour market frictions in the differentiated sector are low and otherwise. Unemployment rates of cross-country differences display rich patterns, this will be evident in ASEAN particularly Philippines.

\section{Government Spending}

Government is the consultant of a country's economic and her activities directly or indirect determine the state of the country's economic growth. Government spending is another important macroeconomic factor that greatly influences economic growth. It deals with government attitude, actions and policies on the country's daily spending and trade. Impact of growth in relation with various spending programmes of government's share on GDP in 28 developing economies. The result found that per capita GDP growth rely on improvement of per capita government health costs, per capita government expenses on education, population growth, share of total health expenditure and gross capital formation. Recommendation was given based on the statistical results that it will be of help for the policymakers; once their government expenditure places in order to stimulate economic growth. Additionally, identified government financial discipline as important fraction in a country's economic growth. Similarly, Kandogan and Johnson (2016) examined the impacts of fiscal freedom reduction that is taxing and spending parts on economic growth. Panel two stage least squares estimation set for the OECD nations was used for analysing. Nominal interest rates, federal government budget deficits and other factors are variables utilized. The result revealed that fiscal freedom direction leads to same way on economic growth; likewise, freedom from 


\section{ENTREPRENEURSHIP AND SUSTAINABILITY ISSUES}

ISSN 2345-0282 (online) http://jssidoi.org/jesi/

2020 Volume 7 Number 3 (March)

http://doi.org/10.9770/jesi.2020.7.3(40)

excessive government size. Also concluded that open trade policies, public and private investment, human capital and government spending were factors militating OECD countries economic evolution. He advocated that for these countries to experience desire economic growth their government must pay close attention to their taxation, government spending and public and private sector development. Urbano, Aparicio, and Audretsch (2019) also argued that economic growth can be enhanced by venture and entrepreneurship capitals. Another that only active venture and entrepreneurship capital enhances economic growth. This infers that venture and entrepreneurship capital is part of the macro-economic factors that contribute to economic growth. Many of these studies were done in Europe and America whereas that there are differences in Africa economic growth factors and the westerners due to long military rule and corruption which is characterized by Africa countries history. They further identified negative spending of the military as a factor militating against economic growth in Africa. This was supported in Ghana that only when Africa countries can abolish military coup, military rule and extreme political mayhem that the continent can experience sustainable economic growth.

Scholar examined the tendencies in government spending in the emerging countries by analysing the factors that influence change and build a framework for defining the different effects of several government expenses on economic development. It is found that all sectors do not receive equal treatment, but SAP increased the size of government spending which was contrary to the general belief. The influence of numerous types of government expenditure on economic growth was also found to be mixed based on Africa, Asia and Latin America context. In ASEAN, promoting economic growth was acknowledged to be strongly supported by government expenditure on agriculture and health; Investments in defense, agriculture and education had positive effects on promoting growth in Asia; while in Latin America, all forms of government expenditures were said to be significant except health expenditure which is found to be insignificant. It was concluded that SAP influence development in Lain America and also in Asia but impeded growth in ASEAN where poverty alleviation solely depends on enhancement of agricultural production with Thailand as a good example. Kargi (2016) investigated "consequence of government spending on the growth from periods of 1980 to 2011. Study adopted the ARDL approach and the deviation from their equilibrium trail. Their results found that government periodic expenses is positively correlated to economic development, whereas affirming the validity of Wagner's law: that states that "increase in responsibilities of any state leads to increases in the economy size in the short and long run". Therefore, it was advised that government should ensure that capital outlay and periodic expenses are well managed appropriately in a way that will boost productive capacity as it will influence the rapid of the growth rate of Thailand economy.

\section{Export}

The beginning of literature on economic growth and export can be traced back to 1970 where many studies (Feddersen, Nel, \& Botha, 2017) used correlation coefficients to analyze relationship between economic growth and export. While in 1980s uses Granger causality methodology to further determine lead and lag relationship. In the 1990s scholars employed the combination of causality test, unit root and cointegration to deeper the understanding of the phenomena. It can be observing that majority of studies support the notion that export positively influence economic growth, however there are some differ options to the notion.

For instance, different studies supported the notion that export positively influence economic growth whereas disagreed with the notion that export positively influence economic growth. These studies findings were recently capture by Dreger and Herzer (2013) that there is no perfect conclusion on the influence of export to economic growth. They observed that it depends on government operation policies. This observation was pointed out that there are possible for economic growth to create inflation pressure leading to low export. Likewise, it is possible for it to produce high interest rate which will also lead to low export. However, they noted that economic growth can boost export if exchange rate favors the country and there is more money in circulation to increase 


\section{ENTREPRENEURSHIP AND SUSTAINABILITY ISSUES}

ISSN 2345-0282 (online) http://jssidoi.org/jesi/

2020 Volume 7 Number 3 (March)

http://doi.org/10.9770/jesi.2020.7.3(40)

productivity (Pamornmast, Jermsittiparsert, \& Sriyakul, 2013a, 2013b; Jermsittiparsert, Pamornmast, \& Sriyakul, 2014).

Amado and Mollo (2015) in his study titled rise and fall of export-led growth (ELG) maintained that ELG causes specialization which enhances productivity of goods and services. The output of productivity is transformation from non-performing trade sector to performing sector. Hence when productivity is positive, and the sector becomes performing then it leads to economic growth. Likewise, that export-led growth enables exporting countries to have more opportunities of manufacturing more goods which open their local market for foreign benefits. This also influences their technological drives and promotes inter-industrial trade. Therefore, export is a vital factor that leads to technological change and economic growth if it's position properly. There is a huge impact of labor market, non-oil exports, physical and human capital stock and import tariffs on Iran's economic growth. They further argued that free trade is an important factor of economic growth.

Study described these mixed findings in two ways, the first was a group of studies using cross-country analysis (Khan \& Abasyn, 2017; Yang \& Mallick, 2014) whereas the second group used single country analysis. He concluded by pointing out that for developing countries to experience sustainable economic growth then there is need to limit their heavy dependency on export of raw on unfinished goods. This is because slight changes in international market will directly affect primary goods which will affect producing countries especially developing countries. This conclusion is similar to Dar and Amirkhalkhali (2017) declaration that the link between export and growth indicates that inward oriented countries should be cautious on policies and practicing strategies. Scholar in Iran suggested that export positively influence economic growth due to net increase in GDP. He revealed that although oil export is playing a significant role in Iran's economic growth now however, the manufacture exports will cause the further economic growth for the country. This finding was further explored when he resolved that there is significant affiliation among export, exchange rate and growth. A similar conclusion was made recently when he extended model by integrating government consumption. He suggested the notion that there is optimistic influence amid government consumption, export and growth.

\section{Agriculture}

While some studies argued that agriculture plays a passive contribution to economic growth. This argument was based on the fact that agriculture provides platform for industrialization and resources. Majority of raw materials inputs needed for advancement both in industries and technology relies on agricultural output. Also, it creates wealth and employment for the normal masses of the country. Hence, these studies concluded that agriculture has a passive role on economic growth. The other arguments counter this position and suggest that agriculture plays a vital and active role on economic growth (Oluwapemi, 2017). It is more like a market on its own than provision of raw resources and material input for productivity and industrialization of a country. In fact, it could be seen that many subsectors like technology and manufacturing benefit greatly from agriculture which means all these sectors inter-dependent on each other. Thus, these two arguments imply that there is disagreement on the true role of agricultural sector on economic growth especially in ASEAN where there are abundant opportunities for agricultural activity. Although, many studies have explored different approaches and method in determining the true position of agricultural sector to economic growth and likewise outlined the theoretical relationship between the two. However, a study maintained that many of the previous studies do not provide conclusive output and position on the impact of agriculture to economic growth. They thereby use conventional regression techniques for their findings. Hence, their finding is inconclusive. Another major study that explains the role of agriculture in economic growth was done. He made two unique arguments that agriculture greatly influences GDP and nonagricultural sector has a little influence on agricultural sector growth. This finding is consistency with Oluwatoyese and Razak (2016) reveals that out of the four foreign sectors namely agricultural, investment, noninvestment and social infrastructure. 


\section{ENTREPRENEURSHIP AND SUSTAINABILITY ISSUES}

ISSN 2345-0282 (online) http://jssidoi.org/jesi/

2020 Volume 7 Number 3 (March)

http://doi.org/10.9770/jesi.2020.7.3(40)

Agriculture sector remains the only sector that positively contributed to economic growth. More recently LUCA et al. (2013) concluded that agricultural sector is one of the major contributions to Romania's economic growth. They argued that farm products and commercial farming are the major factors influencing the economic growth in Romania. Specifically, author pointed out Thailand agriculture sector as a major boost to her economic growth out of all the ASEAN countries. However, calls for in-depth investigation on problems militating against the sector. Researcher highlighted that Thailand government neglect on agriculture sector over oil sector will create a big problem for the country in the future. Hence, he advocated for the need to redirect the country attention to both encompass agriculture and oil for sustainable development of the country.

Furthermore, Oluwatoyese and Razak (2016) maintained that agriculture is the only engine of development that Thailand government can relies on because there are indications that oil sector might crashed. This is the reason why the sector should be well funded and serviced to reduce the mono-cultural dependence on the oil sector. This point supported argument that there is need for Thailand government to increase her budgetary allocation to agriculture section to create a way for the country industrialization and employment. These positions were similar to that there is drop in the influence of agriculture to Thailand 's growth particularly during the oil boom period till now. Hence, this study will investigate the role and influence of agriculture export to economic growth in Thailand.

\section{Oil Price}

Author examined the impact of oil price shocks on Thailand macroeconomic variables using VAR. The study found that oil prices have significant impact on real GDP, money supply and unemployment; while no significant impact on consumer price index. The need for diversification of the economy to minimize the consequences of external shocks is thereby suggested. Similarly, posed a huge challenge on Thailand government. They observed that the total dependence on oil to generate over $80 \%$ of Thailand revenue will negatively affect the country when there is fall in oil price or oil consumption. Export of manufacturing, agriculture and human capital were suggested to reposition the country for future economic growth. This suggestion supported that there is need for Thailand government to diversify her economy and export beyond oil toward solid minerals and agriculture. Also study focused on oil price changes or shock and industrial production relationship used as proxy for economic development. Real exchange rate as one of macroeconomic variables was being analysed by VAR model. Insignificant and indirect statistical effect of prices of oil on production of industry. Once oil price shock affects real exchange rates, industrial production will be affected. However, the results implied increase in industrial production is not as an increment in prices of oil. In another major study Tiba and Omri (2017) examined energy consumption and economic growth relationship. Electricity demand, domestic crude oil consumption and gas utilization are used for the estimation, which are identified as energy consumption's proxies. A long run relationship existed among the series. Furthermore, electricity consumption, domestic crude oil production and gas utilization were found to have unidirectional causality with economic growth. Causality runs from two (gas utilization and electricity consumption) of the proxies used to economic growth as well as from economic growth to domestic production of crude oil. It was therefore concluded that economic growth will be harm by consumption of electricity and gas according to their conservation policy whereas domestic consumption of crude oil regarding policy won't harm (Hussain et al., 2019).

Another study measures of oil value shocks through utilization of previous studies with the perception to determine the degree to which decisions about the petroleum value development definition rely on upon the meaning of the definition of shocks adopted. The study was the pioneering attempt to introduce effects of threshold into shocks of oil price and output linkage. Their findings suggested that oil cost shocks did not justify tangible development in total macroeconomic aggregates, even with the introduction of brink effects. The threshold effects were discovered as weak linkages with the nature of Thailand 's petroleum. The study therefore, concluded that spending of oil income profitably is vital if positive impact on genuine output development is 


\section{ENTREPRENEURSHIP AND SUSTAINABILITY ISSUES}

ISSN 2345-0282 (online) http://jssidoi.org/jesi/

2020 Volume 7 Number 3 (March)

http://doi.org/10.9770/jesi.2020.7.3(40)

anticipated. Similarly, investigated on oil revenue, institutions and macroeconomic indicators such as institutional quality index, money supply, fiscal deficit, inflation, conversion and interest rate over period of time. It was observed that both economic and political strategies are required for managing oil windfalls.

\section{Model specification}

For theoretical specification, growth production model based on Solow (1956), the model in equation 1 is represented in equation

$\boldsymbol{E C G}_{t}=A_{t} F\left(K_{t}, L_{t}\right) \ldots \ldots \ldots(1)$

here ECG denotes aggregate output (GDP), $\mathrm{A}$ is level of technology, $\mathrm{K}$ is capital and $\mathrm{L}$ is labor. Equation 2 can also be expressed as the neoclassical aggregate production function where physical capital $(\mathrm{K})$, human capital $(\mathrm{H})$ and labour (L) are used as inputs for the generalized production function, that is added to equation 2 Schuh (1974) amended the aggregate output (GDP) model in equation 2 as follows:

$\boldsymbol{E C G}_{\boldsymbol{t}}=F\left(f_{T}\left(L a, K_{L a}\right), f_{k}\left(K_{l}, L\right)\right)$

Where, La is land, which was included into the model, $\mathrm{K}$ was put into consideration through the use of KLa and KL. KLa is land augmented capital (biochemical), KLis labour augmented capital (machinery). The KL relates to the $\mathrm{H}$ earlier stated. The level of technology that was denoted by $\mathrm{A}$ in equation 2 was examined to have been captured by the labour augmented capital which is referred to as machinery (KL). The second model is the framework, where the economy was assumed to consist of two sectors: export and non-export, denoted by $\mathrm{X}$ and $\mathrm{N}$ respectively. Each of the sectors are presented to have different production functions with the incorporation of $\mathrm{A}, \mathrm{K}$ and $\mathrm{L}$ as factors to produce output. The Feder's model thereby extended the production function by including $\mathrm{X}$ and $\mathrm{N}$ into equation 3 In addition Al-Yousif (1997) re-modified the output model of equation 3 with the inclusion of $X$ and other factors to be responsible for the aggregate output model as indicated in equation 3 In equation 3, $\mathrm{L}$ and $\mathrm{K}$ remain in the model with the addition of $\mathrm{X}$ as export level, Gas government expenditure and $\mathrm{T}$ as terms of trade. The level of technology denoted by $\mathrm{A}$ in equation 1 that was captured in equation 2 as KL is still retained in equation 3 . This is being represented by $\mathrm{K}$

$\boldsymbol{E C G}_{\boldsymbol{t}}=f(L, L a, K, N, X, G, T) \ldots \ldots \ldots(3)$

Furthermore, Akinbobola and Oyetayo (2010) examined domestic output growth with real exchange rate (Ex). Likewise, investigated on GDP with Ex and other macroeconomic factors such as unemployment rate (Une), government deficit spending $(\mathrm{G})$, interest rate (Int) and inflation rate (Inf). Therefore, the output model as in equation (4) can be expanded as thus:

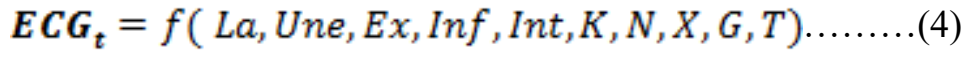

where Une is considered to replace the L. Ex and interest rate (Int) relate based on monetary policy that is associated with $\mathrm{K}$ in equation 4.3. Inf is often considered as a determinant of the exchange rate, which justified the reason for the addition in equation 4.4. This is as a result of an increase in G, leading to increase in output (GDP) and then tends to reduce interest rate (Int). This thereby implies that higher $\mathrm{K}$ puts the pressure of interest rate (Int) downward. This study identifies agricultural export (AGRE) as an export item, therefore substituting AGRE for X. Agricultural output (AGROU) and crude oil price (CROP) as non-export item by replacing $\mathrm{N}$ with AGROU and CROP. However, to achieve the second objective which is to examine the impact of macroeconomic factors on economic growth; equations from 4.2 to 4.3 are modified. Likewise, in line with equation 4 this study presents equation 5 to examine the second objective, which considered the addition of crude oil price and agricultural export to the economic growth equation.

$\boldsymbol{E C G}_{\boldsymbol{t}}=f\left(\right.$ Une $\left._{,} E x_{,}, \operatorname{Inf}, \operatorname{Int}, A G R E, A G R O U_{,} C R O P\right)$

Likewise, for agricultural output model equation 6 was adapted, where GDP can be equal to agricultural output. The macroeconomic factors affecting output model can also be linked to be affecting agricultural output, as stated from equation 1 to 4 . Therefore

$\boldsymbol{A G R O U}_{t}=f\left(L a\right.$, Une $\left._{,} E x_{,} \operatorname{Inf}, \operatorname{Int}_{,} K_{,} N_{,}, X_{y}, T\right) \ldots \ldots \ldots(6)$ 


\section{ENTREPRENEURSHIP AND SUSTAINABILITY ISSUES}

ISSN 2345-0282 (online) http://jssidoi.org/jesi/

2020 Volume 7 Number 3 (March)

http://doi.org/10.9770/jesi.2020.7.3(40)

The relationship between agricultural land and agricultural output growth in this study is based on Schuh (1974) model in equation 2. However, the relationship between government spending and agriculture is based on Ram (1986) framework. Ram's framework is based exports and output growth model. Also a model which followed Ram (1986) assumed that the economy consists of government (G) and non-government (C) sector. This model is represented by equation

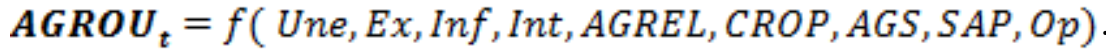

Equation 7 however, links agricultural output to some of the macroeconomic factors (Ex, Int, Une, Inf and Op) associated with output in addition with new variables. Introduction of new variables such as agricultural land (AGRELL), SAP, crude oil price and government spending on agriculture (AGS) was made in an attempt to answer the stated third objective. Moreover, to achieve the fourth objective on investigating the impact of CROP, SAP and AGS on agricultural export, this study follows the theoretical specification in consider agricultural export as dependent variable. Author simplified the agricultural export model as follow

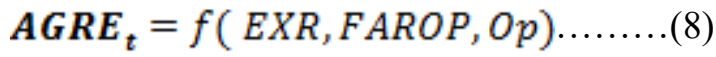

where FAROP is the farm output prices, Ex is the exchange rate and Op is openness. Also, Ali, Abou-Mesalam, and El-Shorbagy (2010) considered exchange rate (EXR), interest rate (Int), inflation rate (Inf) and money supply (M) to determine agricultural export as indicated in equation 9

$\boldsymbol{A G R E}_{t}=f\left(E X R_{,} \operatorname{Int} \cdot \operatorname{In} f, M\right)$

However, based on equation 8 and 9, agricultural export in this study will be determined with equation 4.10 with the inclusion of variables such as CROP, SAP and AGS. The relationship between agricultural export and government spending on agriculture is based on export supply function, therefore AGS is used to replace M in equation 9. Hence, the FAROP in equation 8 was represented by CROP. SAP is a policy made by the government. $A G R E_{t}=f(E X R, \operatorname{Int} . \operatorname{Inf}, S A P, C R O P . A G S, O p)$.

In an attempt to determine the relationship between dependent and independent variables in Thailand, models are specified as:

$\boldsymbol{E} \boldsymbol{C G} \boldsymbol{G}_{\boldsymbol{t}}=$

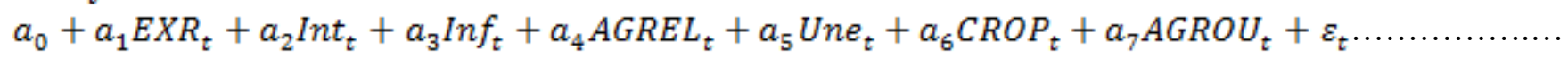

$\operatorname{AGROU}_{t}=$

$a_{0}+a_{1} E X R_{t}+a_{2} \operatorname{Int}_{t}+a_{3} \ln f_{t}+a_{4} A G R E L_{t}+a_{5}$ Une $_{t}+a_{6}$ CROP $_{t}+a_{7} A G S_{t}+a_{8} S A P_{t}+$

$a_{9} O p_{t}+\varepsilon_{t}$

$\boldsymbol{A G R E}_{t}=a_{0}+a_{1}$ EXR $_{t}+a_{2} \operatorname{Int}_{t}+a_{3} \operatorname{Inf}_{t}+a_{4} U n e_{t}+a_{5}$ CROP $_{t}+a_{6} A G S_{t}+a_{7} S A P_{t}+\varepsilon_{t} \ldots$ (13)

ARDL is a method developed for the cointegration analysis by Pesaran and Shin (1998). It is applicable regardless of the stationarity of variables; that is variables mainly I (0) or I (1) and with mixed results are used. In terms of the number of variables, more are required than in VAR models. It allows for identification of long-run and short-run changes on the dependent variable. The ARDL based method yields a consistent estimation of the long-run coefficients that are asymptotically normal. It could be relied on when using small samples for estimation and hypotheses testing on the long-run coefficient. The pretesting problem that is indirectly involved in the cointegration analysis can be avoided by the ARDL approach. There is no priori exogenous and endogenous division of variables in the model. Likewise, zero restrictions are not forced and no strict theory of economic in which the model is developed. In addition, a dynamic ECM can be derived from this approach through a simple linear transformation. However, to illustrate ARDL model approach, this model is considered. 


$$
\begin{aligned}
& \Delta \boldsymbol{E C G}_{t}=\frac{a_{0}}{\mu(1)}+a_{1} \text { EXR }_{t}+a_{2} \operatorname{Int}_{t}+a_{3} \operatorname{Inf}_{t}+a_{4} \text { AGRE }_{t}+a_{5} \text { Une }_{t}+a_{6} \text { CROP }_{t}+a_{7} \text { AGROU } \\
& \frac{1}{\mu(1)} \sum_{i=1}^{m_{1}-1} a_{1} \Delta E X R_{t-1}+\frac{1}{\mu(1)} \sum_{i=1}^{m_{n}-1} a_{2} \Delta \operatorname{In} t_{t-1}+\frac{1}{\mu(1)} \sum_{i=1}^{m_{n}-1} a_{3} \Delta \ln f_{t-1}+ \\
& \frac{1}{\mu(1)} \sum_{i=1}^{m_{4}-1} a_{4} \Delta A G R E_{t-1}+\frac{1}{\mu(1)} \sum_{i=1}^{m_{5}-1} a_{5} \Delta U n e_{t-1}+\frac{1}{\mu(1)} \sum_{i=1}^{m_{6}-1} a_{6} \Delta C R O P_{t-1}+ \\
& \frac{1}{\mu(1)} \sum_{i=1}^{m_{7}-1} a_{7} \triangle A G R O U_{t-1} \\
& \Delta \text { AGROU }_{t}=\frac{a_{0}}{\mu(1)}+a_{1} \text { EXR }_{t}+a_{2} \text { Int }_{t}+a_{3} \operatorname{Inf}_{t}+a_{4} \text { AGREL }_{t}+a_{5} \text { Une }_{t}+a_{6} \text { CROP }_{t}+a_{7} A C \\
& a_{6} S A P_{t}+a_{7} O p_{t}+\frac{1}{\mu(1)} \sum_{i=1}^{m_{1}-1} a_{1} \Delta E X R_{t-1}+\frac{1}{\mu(1)} \sum_{i=1}^{m_{2}-1} a_{2} \Delta \operatorname{In} t_{t-1}+\frac{1}{\mu(1)} \sum_{i=1}^{m_{\mathrm{g}}-1} a_{3} \Delta \operatorname{In} f_{t-1} \\
& \frac{1}{\mu(1)} \sum_{i=1}^{m_{4}-1} a_{4} \triangle A G R E L_{t-1}+\frac{1}{\mu(1)} \sum_{i=1}^{m_{5}-1} a_{5} \Delta U n e_{t-1}+\frac{1}{\mu(1)} \sum_{i=1}^{m_{6}-1} a_{6} \Delta C R O P_{t-1}+ \\
& \frac{1}{\mu(1)} \sum_{i=1}^{m_{y}-1} a_{7} \Delta A G S_{t-1}+\frac{1}{\mu(1)} \sum_{i=1}^{m_{g}-1} a_{8} \Delta S A P_{t-1}+\frac{1}{\mu(1)} \sum_{i=1}^{m_{g}-1} a_{9} \Delta O p_{t-1}
\end{aligned}
$$

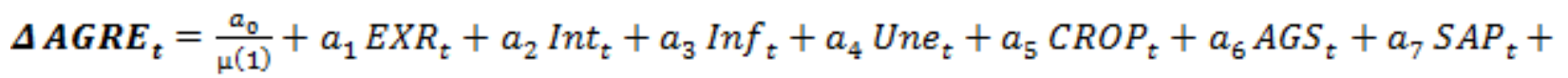

$$
\begin{aligned}
& \frac{1}{\mu(1)} \sum_{i=1}^{m_{1}-1} a_{1} \Delta E X R_{t-1}+\frac{1}{\mu(1)} \sum_{i=1}^{m_{n}-1} a_{2} \Delta \operatorname{Int} t_{t-1}+\frac{1}{\mu(1)} \sum_{i=1}^{m_{n}-1} a_{3} \Delta \ln f_{t-1}+ \\
& \frac{1}{\mu(1)} \sum_{i=1}^{m_{4}-1} a_{4} \Delta U n e_{t-1}+\frac{1}{\mu(1)} \sum_{i=1}^{5-1} a_{5} \Delta C R O P_{t-1}+\frac{1}{\mu(1)} \sum_{i=1}^{m_{6}-1} a_{6} \Delta A G S_{t-1}+\frac{1}{\mu(1)} \sum_{i=1}^{m_{7}-1} a_{7} \Delta s+\varepsilon_{t} \ldots(15)
\end{aligned}
$$

\begin{tabular}{|c|c|c|c|c|c|c|c|c|c|c|c|c|}
\hline & & 1 & 2 & 3 & 4 & 5 & 6 & 7 & 8 & 9 & 10 & 11 \\
\hline$E C G$ & 1 & 1 & & & & & & & & & & \\
\hline EXR & 2 & $0.830^{* *}$ & 1 & & & & & & & & & \\
\hline Int & 3 & $0.257 * *$ & $0.243 * *$ & 1 & & & & & & & & \\
\hline$A G R O U$ & 4 & $0.810^{*}$ & $0.118 * *$ & $0.829 *$ & 1 & & & & & & & \\
\hline Inf & 5 & $0.145^{* *}$ & $0.463^{*}$ & 0.129 & $0.579^{*}$ & 1 & & & & & & \\
\hline AGREL & 6 & $0.130^{*}$ & $0.247 * *$ & 0.828 & $0.674^{*}$ & 0.882 & 1 & & & & & \\
\hline Une & 7 & $0.234 * *$ & $0.323 * *$ & $0.212^{*}$ & $0.214^{*}$ & $0.352 *$ & $0.653^{*}$ & 1 & & & & \\
\hline CROP & 8 & $0.342 * *$ & $0.091 * *$ & $0.052^{*}$ & $0.541^{*}$ & $0.152 *$ & $0.109^{*}$ & $0.899^{*}$ & 1 & & & \\
\hline$A G S$ & 9 & $0.621 * *$ & $0.111 * *$ & $0.321 *$ & $0.271^{*}$ & $0.111 *$ & $0.231 *$ & $0.112^{*}$ & $0.059 *$ & 1 & & \\
\hline$S A P$ & 10 & $0.190^{* *}$ & $0.101 * *$ & $0.871^{*}$ & $0.321^{*}$ & $0.761 *$ & $0.271^{*}$ & $0.828^{*}$ & $0.674 *$ & 0.882 & 1 & \\
\hline$O p$ & 11 & $0.982 * *$ & $0.301 * *$ & $0.901^{*}$ & $0.391^{*}$ & $0.871^{*}$ & $0.222^{*}$ & $0.829^{*}$ & $0.271^{*}$ & 0.129 & 0.829 & 1 \\
\hline
\end{tabular}

\section{Results}

The results of the correlation test between dependent variable and independent variables proved to be very useful in pre estimation analysis especially as regards potential relationships suggested by theories. Therefore prior to the econometrics analysis, the statistical correlation of the variables are examined which helped in determining the statistical relationships between and amongst the variables. See Table 1 below.

Table 1. Correlation Analysis

Table 2 summarize the results of GDP, agricultural output and agricultural export models respectively based on the selected ARDL models. An ARDL $(1,0,0,1,1,1,0,1)$ was chosen for the GDP model. The results of R2 (78.7\%), the adjusted R2 (65.9\%) in Table 5.6 along with the F-statistic for GDP equation model show that the 
model obtained best goodness of fit and variations of the selected independent variables explained certain the changes of the dependent variable. The significance of the F-statistics test justifies the inclusion of all the explanatory variables existing in the GDP model.

Table 2. Optimal ARDL Model Selection

\begin{tabular}{|c|c|c|c|c|}
\hline Variables & Coefficients & Standard Error & $t$-statistics & $p$-Value \\
\hline \multicolumn{5}{|c|}{ Model 1: ARDL $(0,0,0,0,0,0,1)$} \\
\hline EXR & 0.415 & 0.142 & 2.922 & $0.008 *$ \\
\hline Int & 0.455 & 0.147 & 3.090 & $0.006^{*}$ \\
\hline AGROU & 0.000 & 0.000 & 2.427 & $0.024 *$ \\
\hline $\operatorname{InT}$ & 0.000 & 0.000 & 5.938 & $0.000 *$ \\
\hline AGREL & -0.477 & 0.137 & -3.498 & $0.002 *$ \\
\hline Une & 0.001 & 0.001 & 2.202 & $0.003 * *$ \\
\hline CROP & 0.023 & 0.043 & 3.526 & 0.000 \\
\hline CROP(-1) & 0.065 & 0.037 & 1.763 & $0.092 * *$ \\
\hline $\mathrm{C}$ & 7.406 & 2.882 & 2.570 & $0.018^{*}$ \\
\hline $\mathrm{T}$ & 0.045 & 0.009 & 4.731 & $0.000 * * *$ \\
\hline \multicolumn{5}{|c|}{ Model 2: ARDL (10,0,0,0,0,0,0,0) } \\
\hline EXR & 0.425 & 0.183 & 2.327 & $0.001 *$ \\
\hline $\operatorname{EXR}(-1)$ & 0.340 & 0.173 & 2.959 & $0.005^{* *}$ \\
\hline Int & 0.000 & 0.000 & 3.401 & $0.007 * *$ \\
\hline AGREL & 0.000 & 0.000 & 4.338 & $0.000 *$ \\
\hline Une & -0.428 & 0.195 & -2.201 & $0.040 *$ \\
\hline CROP & 0.045 & 0.056 & 2.915 & $0.031 *$ \\
\hline Inf & 0.033 & 0.057 & 3.570 & $0.005^{* *}$ \\
\hline AGS & 0.103 & 0.062 & 4.675 & $0.000^{* *}$ \\
\hline SAP & 0.033 & 0.048 & 3.689 & $0.021 * *$ \\
\hline OP & 0.097 & 0.053 & 2.831 & $0.083^{* *}$ \\
\hline $\mathrm{C}$ & 11.399 & 5.234 & 2.178 & $0.042 *$ \\
\hline $\mathrm{T}$ & 0.070 & 0.023 & 2.992 & $0.007 *$ \\
\hline \multicolumn{5}{|c|}{ Model 3: ARDL $(\mathbf{0 , 0 , 0 , 0 , 0 , 0 , 0 , )}$} \\
\hline EXR & 0.429 & 0.118 & 3.624 & $0.001 *$ \\
\hline Inf & 0.000 & 0.000 & 4.158 & $0.000 *$ \\
\hline CORP & 0.000 & 0.000 & 1.902 & $0.070 * *$ \\
\hline Int & 0.000 & 0.000 & -3.352 & $0.003^{*}$ \\
\hline Une & -1.214 & 0.380 & -3.194 & $0.004 *$ \\
\hline AGS & -0.291 & 0.076 & 3.854 & $0.001 *$ \\
\hline SAP & 0.418 & 0.113 & 3.709 & $0.001 *$ \\
\hline $\mathrm{C}$ & 25.974 & 6.203 & 4.188 & $0.000 *$ \\
\hline
\end{tabular}

Table 2 reveals that almost all the coefficients of the regressors included in the specified model happens to be significant at a point in time except for exchange rate, government spending on agriculture, SAP, a year lagged of openness and agricultural land having negative signs and insignificant. The R2 (97.7\%) and adjusted R2 (89.7\%) values suggest that the model has a high explanatory power. The one year lagged dependent variable that is agricultural output for the country was found to be statistically significant implying that the preceding year's output does influence the current nation's output. An ARDL $(2,2,2,0,2,2,2)$ model was selected for 


\section{ENTREPRENEURSHIP AND SUSTAINABILITY ISSUES}

ISSN 2345-0282 (online) http://jssidoi.org/jesi/

2020 Volume 7 Number 3 (March)

http://doi.org/10.9770/jesi.2020.7.3(40)

agricultural export. Table 2 shows the results of the ARDL estimates for agricultural export model. Nearly all the variables are statistically significant with expected signs. A year and 2 years lagged dependent variable that is agricultural export for the nation was found to be significant implying that past years' export does influence the current nation's export. The R2 (87.5\%) and adjusted R2 (64.7\%) values are quite high, which reflects that nearly all of the variations in the dependent variable (agricultural export) are being explained by the estimation model.

\section{Conclusion}

The main objective of the study can be looked at from the theoretical and practical perspectives thereby predicated on the researcher's strong will to contribute to the body of knowledge by analyzing the economic impact of government spending on agriculture, unemployment rate, and crude oil price in the context of agriculture sector of non-oil for economic growth. Moreover, with the aims to bridge the literature gap in the knowledge of macroeconomic factors on the agriculture in Thailand ; since the non-oil export has the potential of growth in terms of sales, profitability, rate of earnings and productivity if the factors militating against the non-oil exports are addressed. Likewise, Sindhu et al. (2018) concluded that stabilization economic policies that will boost export promotion and productivity should be sustained and implemented; in wise of government policies stimulating agricultural productivity being examined. This will be of important for policy making in developing countries of the world especially Thailand for the design of macroeconomic policies in order to promote export through the aid of the agriculture sector; whereas leading towards improvement in economic growth. Likewise, since the role of agriculture in transforming the economy cannot be overstressed by serving as the source of food for human and animal and provides raw materials for industrial sector. Evidences by most economists based on the 1970s and 1980s experiences assumed that good macroeconomic policies are essential and adequate for the achievement of sustainable growth in the long run. Hence, macroeconomic factors which consists of fiscal, monetary and trade policies influence economic growth. Since all the policies (fiscal, trade and monetary) are interdependent, macroeconomic policies can therefore be defined as policy mix. Thailand as an example of a developing nations has embraced various policy mix in the means of improving the overall feasibility of the country's economy performance. Although several policies are being designed by the government to improve Thailand's economy as a whole, some policies often have causal and detrimental effects on output growth. For instance, the falling of global commodity price and increasing of world crude prices of recent have become more challenging for government in stimulating the economy without endangering macroeconomic stability (Gilpin, 2018). Hence, associate the improvement of macroeconomic factors to be anchored to the nations' growth.

\section{References}

Adegboyo, O. S. (2019). The nexus between exchange rate fluctuations and macroeconomic variables in Nigeria. Jurnal Perspektif Pembiayaan Dan Pembangunan Daerah, 6(4), 489-502. https://doi.org/10.22437/ppd.v6i4.6202

Adekunle, W., \& Ndukwe, C. I. (2018). The impact of exchange rate dynamics on agricultural output performance in Nigeria. https://mpra.ub.uni-muenchen.de/id/eprint/87755

Akinbobola, T., \& Oyetayo, O. (2010). Econometric Analysis of Real Exchange Rate And Domestic Output Growth In Nigeria. International Journal of Academic Research, 2(5).

Al-Yousif, Y. K. (1997). Exports and economic growth: Some empirical evidence from the Arab Gulf countries. Applied Economics, 29(6), 693-697. https://doi.org/10.1080/000368497326624

Ali, H. M., Abou-Mesalam, M., \& El-Shorbagy, M. (2010). Structure and optical properties of chemically synthesized titanium oxide deposited by evaporation technique. Journal of Physics and chemistry of Solids, 71(1), 51-55. https://doi.org/10.1016/j.jpcs.2009.10.008 


\section{ENTREPRENEURSHIP AND SUSTAINABILITY ISSUES}

ISSN 2345-0282 (online) http://jssidoi.org/jesi/

2020 Volume 7 Number 3 (March)

http://doi.org/10.9770/jesi.2020.7.3(40)

Amado, A. M., \& Mollo, M. d. L. R. (2015). The 'developmentalism' debate in Brazil: some economic and political issues. Review of Keynesian Economics, 3(1), 77-89. https://doi.org/10.4337/roke.2015.01.06

Bagli, S., \& Adhikary, M. (2014). FDI inflow and economic growth in India an empirical analysis. Economic Affairs, 59(1), 23. https://doi.org/10.5958/j.0976-4666.59.1.003

Barro, R. J. (2016). Economic growth and convergence, applied especially to China: National Bureau of Economic Research. https://doi.org/doi:10.1111/cwe.12172

Berg, H., \& Lewer, J. J. (2015). International trade and economic growth: Routledge. https://doi.org/10.4324/9781315703282

Bodenstein, M., Erceg, C. J., \& Guerrieri, L. (2017). The effects of foreign shocks when interest rates are at zero. Canadian Journal of Economics/Revue canadienne d'économique, 50(3), 660-684. https://doi.org/10.17016/IFDP.2016.983r

Bon, N. V. (2018). Inflation and the public investment: Growth relationship in Vietnam. https://doi.org/10.24311/jed\%2F2018.25.S01.6

Bruno, V., \& Shin, H. S. (2015). Capital flows and the risk-taking channel of monetary policy. Journal of Monetary Economics, 71, 119132. https://doi.org/10.1016/j.jmoneco.2014.11.011

Caurkubule, Zh. L., Kenzhin, Zh. B. Bekniyazova, D.S., Bayandina, G.D., Dyussembekova, G. S. 2020. Assessment of competitiven ess of regions of the Republic of Kazakhstan. Insights into Regional Development, 2(1), 469-479. http://doi.org/10.9770/IRD.2020.2.1(6)

Chand, K., Tiwari, R., \& Phuyal, M. (2017). Economic Growth and Unemployment Rate: An Empirical Study of Indian Economy. PRAGATI: Journal of Indian Economy, 4(2), 130-137. https://doi.org/10.17492/pragati.v4i02.11468

Cylus, J., Glymour, M. M., \& Avendano, M. (2014). Do generous unemployment benefit programs reduce suicide rates? A state fixedeffect analysis covering 1968-2008. American journal of epidemiology, 180(1), 45-52. https://dx.doi.org/10.1093\%2Faje\%2Fkwu106

Danylova, T., \& Kats, L. (2019). " All animals are equal, but some animals are more equal than others": The negtive impact of gender inequality on the global economy and public health. Anthropological Measurements of Philosophical Research(15), 101-110. https://doi.org/10.15802/ampr.v0i15.168842

Dar, A., \& Amirkhalkhali, S. (2017). Fiscal Policy, Total Factor Productivity and Economic Growth in Advanced Economies. Applied Econometrics and International Development, 17(2), 5-18.

Doki, N. O., Ochinyabo, S., \& Sule, A. (2018). Agricultural Export and the Diversification of the Nigerian Economy. Journal of Economics and Finance, 2(1), 259-273.

Dreger, C., \& Herzer, D. (2013). A further examination of the export-led growth hypothesis. Empirical Economics, 45(1), 39-60. https://dx.doi.org/10.2139/ssrn.1927245

Eddelani, O., El Idrissi, N. E., Monni, S. (2019.) Territorialized forms of production in Morocco: provisional assessment for an own model in gestation. Insights into Regional Development, 1(1), 6-18. https://doi.org/10.9770/ird.2019.1.1(1)

Esu, G. E., \& Udonwa, U. (2015). Economic diversification and economic growth: Evidence from Nigeria. Journal of Economics and Sustainable Development, 6(16), 56-68.

Fariditavana, H. (2016). Exchange rate changes and the trade balance: Is the link symmetric or as?,,, The University of WisconsinMilwaukee.

Feddersen, M., Nel, H., \& Botha, F. (2017). Exports, capital formation and economic growth in South Africa. African Review of Economics and Finance, 9(1), 213-244.

George-Anokwuru, C. C. (2018). Economic Globalization and Growth of the Nigerian Economy. International Journal of Economics and Business Management, 4(2), 51-60.

Gilpin, R. (2018). The challenge of global capitalism: The world economy in the 21st century: Princeton University Press.

Habib, M. M., Mileva, E., \& Stracca, L. (2017). The real exchange rate and economic growth: Revisiting the case using external instruments. Journal of International Money and Finance, 73, 386-398. http://dx.doi.org/10.1016/j.jimonfin.2017.02.014

Hassan, M., \& Nassar, R. (2017). Economic Factors Predicting Inflation In The US, England, France, and Germany. Global Journal of Accounting and Finance, 1(2), 35-48. 


\section{ENTREPRENEURSHIP AND SUSTAINABILITY ISSUES}

ISSN 2345-0282 (online) http://jssidoi.org/jesi/

2020 Volume 7 Number 3 (March)

http://doi.org/10.9770/jesi.2020.7.3(40)

Hussain, H.I., Grabara, J., Razimi, M.S.A., \& Sharif, S.P. (2019) Sustainability of Leverage Levels in Response to Shocks in Equity Prices: Islamic Finance as a Socially Responsible Investment, Sustainability, 11 (12), 3260. https://doi.org/10.3390/su11123260

Jermsittiparsert, K., Pamornmast, C., \& Sriyakul, T. (2014). An Empirical Discourse Analysis on Correlations between Exchange Rate and Industrial Product Export. International Business Management, 8(5), 295-300.

Kaas, L., \& Kircher, P. (2015). Efficient firm dynamics in a frictional labor market. American Economic Review, 105(10), 3030-3060. http://dx.doi.org/10.1257/aer.20131702

Kandogan, Y., \& Johnson, S. D. (2016). Role of economic and political freedom in the emergence of global middle class. International Business Review, 25(3), 711-725. http://dx.doi.org/10.1016/j.ibusrev.2015.02.005

Kargi, B. (2016). Is Wagner's law applicable for fast growing economies? BRICS and MATIK countries. Timisoara Journal of Economics and Business, 9(1), 1-15. https://doi.org/10.1515/tjeb-2016-0001

Kashi, F. K., \& Tash, M. N. S. (2014). Effects of macroeconomic variables on poverty in Iran (Application of bootstrap technique). Theoretical and Applied Economics, 21(5), 594.

Keho, Y. (2017). The exports and economic growth nexus in Cote D'ivoire: Evidence from a multivariate time series analysis. Asian Journal of Economic Modelling, 5(2), 135-146. http://dx.doi.org/10.18488/journal.8/2017.5.2/8.2.135.146

Khan, M., \& Abasyn, J. (2017). An exploratory evidence of the types of challenges and opportunities perceived by the Small and Medium Enterprises (SMEs) in the apparel export sector of Pakistan. University Journal of Social Sciences, 10(2), 373-395.

Lewis, W. A. (2013). Theory of economic growth: Routledge.

Lincényi, M., Č́rsky, J. 2020. Policy trusts in public policy in the Slovak Republic. Insights into Regional Development, 2(1), 456-468. http://doi.org/10.9770/IRD.2020.2.1(5)

Luca, L., Cionga, C., \& Giurca, D. (2013). An estimation of the effects of selected farm consolidation measures on the economic growth in Romanian agriculture. Agronomy Series of Scientific Research/Lucrari Stiintifice Seria Agronomie, 56(2).

Maravalle, A., \& Rawdanowicz, Ł. (2018). Changes in Economic and Financial Synchronisation. : http://dx.doi.org/10.1787/ba7c5c04-en

Meade, J. E. (2013). A Neo-Classical Theory of Economic Growth (Routledge Revivals): Routledge.

Mohsen, A. S. (2015). Effects of oil and non-oil exports on the economic growth of Syria. Academic Journal of Economic Studies, 1(2), 69-78.

Obi, K. O., Yuni, D. N., \& Ihugba, O. A. (2016). Inflation and growth nexus in Nigeria: An investigation into the simultaneous relationship. International Journal of Development and Economic Sustainability, 4(3), 25-32.

Oluwapemi, O. O. (2017). Impact of macroeconomic factors on economic growth, agricultural output and export in Nigeria. Universiti Utara Malaysia.

Oluwatoyese, O. P., \& Razak, N. A. A. (2016). Macroeconomic factors and agricultural sector in Nigeria. Procedia-Social and Behavioral Sciences, 219, 562-570. http://dx.doi.org/10.1016/j.sbspro.2016.05.035

Pamornmast, C., Jermsittiparsert, K., \& Sriyakul, T. (2013a). An Empirical Discourse Analysis on Correlations between the Exchange Rate and Exports of Agricultural Product Export. PSAKU International Journal of Interdisciplinary Research, 2(1), 48-62. http://dx.doi.org/10.12778/235108618X15452373185138

Pamornmast, C., Jermsittiparsert, K., \& Sriyakul, T. (2013b). Exchange Rate and Nation's Export Competitiveness: An Empirical Discourse Analysis. Asian Social Science, 9(13), 147-156. http://dx.doi.org/10.5539/ass.v9n13p147

Pesaran, M. H., \& Shin, Y. (1998). An autoregressive distributed-lag modelling approach to cointegration analysis. Econometric Society Monographs, 31, 371-413. https://doi.org/10.1017/CCOL521633230.011

Ram, R. (1986). Government size and economic growth: A new framework and some evidence from cross-section and time-series data. The American Economic Review, 76(1), 191-203.

Rashwan, Ragheb, M. A., \& Bary, A. A. (2018). The Role of Branding on Educational Performance in the Egyptian Private Universities. Open Access Library Journal, 5(10), 1. https://doi.org/10.4236/oalib.1104882 


\section{ENTREPRENEURSHIP AND SUSTAINABILITY ISSUES}

ISSN 2345-0282 (online) http://jssidoi.org/jesi/

2020 Volume 7 Number 3 (March)

http://doi.org/10.9770/jesi.2020.7.3(40)

Schuh, G. E. (1974). The exchange rate and US agriculture. American Journal of Agricultural Economics, 56(1), 1-13. https://doi.org/10.2307/1239342

Scott, K. D. (2015). CNY \& USD: Foreign Exchange Rates.

Sindhu, M. A., Babar, Z. A., \& Abbas, A. (2018). Analyzing the Relationship of Energy Consumption, Consumer Expenditures and Economic Growth: A Case Study of Pakistan. Journal of Research in Social Sciences, 6(1), 153-164.

Solow, R. M. (1956). A contribution to the theory of economic growth. The quarterly journal of economics, 70(1), 65-94. https://doi.org/10.2307/1884513

Tiba, S., \& Omri, A. (2017). Literature survey on the relationships between energy, environment and economic growth. Renewable and Sustainable Energy Reviews, 69, 1129-1146. https://doi.org/10.1016/j.rser.2016.09.113

Urbano, D., Aparicio, S., \& Audretsch, D. B. (2019). Social Progress Orientation, Entrepreneurship and Economic Development Institutions, Entrepreneurship, and Economic Performance (pp. 107-129): Springer. http://dx.doi.org/10.1007/978-3-030-13373-3_5

Verter, N., \& Bečvářová, V. (2016). The impact of agricultural exports on economic growth in Nigeria. Acta Universitatis Agriculturae et Silviculturae Mendelianae Brunensis, 64(2), 691-700. http://dx.doi.org/10.11118/actaun201664020691

Vigliarolo, F. (2020). Economic phenomenology: fundamentals, principles and definition. Insights into Regional Development, 2(1), 418429. http://doi.org/10.9770/IRD.2020.2.1(2)

Yang, Y., \& Mallick, S. (2014). Explaining cross-country differences in exporting performance: The role of country-level macroeconomic environment. International Business Review, 23(1), 246-259. https://doi.org/10.1016/j.ibusrev.2013.04.004

Zeibote, Z.; Volkova, T.; Todorov, K. 2019. The impact of globalization on regional development and competitiveness: cases of selected regions, Insights into Regional Development 1(1): 33-47. https://doi.org/10.9770/ird.2019.1.1(3)

Paitoon CHETTHAMRONGCHAI is a lecturer of Department of Marketing, Kasetsart Business School, Thailand. He holds Ph.D. in Marketing Management from the University of Manchester, England. His areas of expertise are Marketing Management and Modern Management.

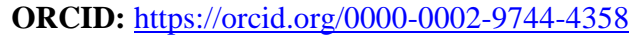

Sudawan SOMJAI is an Assistant Professor and Director of the Doctor of Philosophy Program in Development Administration, Suan Sunandha Rajabhat University, Thailand. Her research areas are Public and Private Administration, Development Administration, Leadership and Social Sciences Research and have many articles in these areas.

ORCID: $\underline{\text { https://orcid.org/0000-0002-8294-8166 }}$

Thitinan CHANKOSON is an Assistant Professor of Business Administration at the Faculty of Business Administration for Society, Srinakharinwirot University, Thailand. He holds a Doctor of Science in International Service Business Management from North Eastern University, Thailand. His research interests are service business management, aviation management, international business management, supply chain management, and tourism and hospitality industry.

ORCID: https://orcid.org/0000-0003-1855-678X

Copyright (C) 2020 by author(s) and VsI Entrepreneurship and Sustainability Center

This work is licensed under the Creative Commons Attribution International License (CC BY).

http://creativecommons.org/licenses/by/4.0/

CC) $\underset{\mathrm{EY}}{\mathrm{B}}$ Open Access 